\title{
Testicular Trophoblastic Tumor
}

National Cancer Institute

\section{Source}

National Cancer Institute. Testicular Trophoblastic Tumor. NCI Thesaurus. Code C39934.

A tumor that arises from the testis and is composed of neoplastic trophoblastic cells.

The vast majority of cases are choriocarcinomas. 